\title{
Neo-Agro-Colonialism, Control over Life, and Imposed Spatio-Temporalities
}

\author{
Matheus Hoffmann Pfrimer ${ }^{*}$ \\ Ricardo César Barbosa Júnior**
}

\begin{abstract}
The control over what Dillon and Lobo-Guerrero (2008) conceptualise as 'pluripotent' life has become an essential factor of capitalist agriculture; this occurs through the regulation of strategic genetic resources. We recognise this course as part of a larger project of neo-agro-colonialism, which takes place by controlling both biotechnology and territories as an expression of a fungible power, turning geopolitics into biopolitics and vice-versa. While assessing the power relations and manipulation of spatio-temporalities in the process of life fabrication, we discuss the mechanisms of control over 'pluripotent' life - genetically modified seeds and biopiracy through patentisation of traditional knowledges - which turns life into a commodified good. This is to say that the instrumental use of life fabrication within the rationale of globalised capital (re)creates post-colonial temporalities that legitimise (re)new(ed) colonial ties. We ascertain that it is the manipulation of life's temporality that allows capital to be (re)produced in the agricultural context of the molecular age.
\end{abstract}

Keywords: Neo-Agro-Colonialism; Temporalities; Biopolitics; Biotechnology; 'Pluripotent' Life; Agriculture; Seeds.

\section{Introduction}

Even though colonialism in its original sense - where a territory exerted direct control over another - has mostly disappeared, many of the same power relations mark the postcolonial world. Countries and their populations are still in conditions of disparity, with the flow of natural resources not having ceased and even less so - as would arguably be more just - reversed. The basis of this dynamic still remits many of the traditional temporalities of colonialism, but the form and means are now quite different.

In the same way that slave labour transitioned to salaried employment, direct colonial dominance becomes mostly obsolete within a globalised market, and thus colonial ties take on a new form. Now resources can be extracted by the actions of transnational capital

\footnotetext{
* Federal University of Goiás, Goiânia-GO, Brazil; matheuspfrimer@hotmail.com.

** Federal University of Goiás, Goiânia-GO, Brazil; ribarbosajr@gmail.com.
} 
in an international market that institutionalises inequalities while still having the audacity to call itself 'free'. However, not all resources traded hold a mere market value; some are essential for the perpetuation of life. It is in this context, through a process that can be understood as neo-colonial, that we discuss the novel forms in which agriculture has become assimilated, which we call neo-agro-colonialism. This is done by considering the bio/geopolitical implications of efforts aimed at controlling agricultural (re)production and trade, facilitated by the scientific and technological developments of molecular biology in recent years. In this process, we specifically centre our analysis on the seed question.

Dependence is a key aspect of colonialism, but in many ways, when it comes to food, it is the coloniser that is dependent on the colonised (Patnaik 2015). This transmuted relation creates the need for, and accentuates the particular significance of, the use of contrivances by the coloniser that once again reverse this dynamic. Thus arises the necessity to understand which mechanisms exist that allow this course to be perceived as legitimate. Motivated by the suspicion that alternative temporalities are (re)created by the use of biotechnology in the control over 'pluripotent' life (Dillon and Lobo-Guerrero 2008) within the described development, we ask which colonial temporalities are being (re)introduced in the use of biotechnology as a security apparatus to exert control over life itself.

Even though discussing biotechnology in the social sciences is becoming a trend (Castree and Braun 2002; Rose 2007b; Landecker 2010; Cooper 2015), traditional academic literature that broaches this topic's relationship with colonialism is emerging (Shiva 2001; Graddy 2014). In this work, we give more emphasis to the system of concepts - such as the fungibility between geopolitics and biopolitics - and their significance, which reflect ideas within the course we seek to understand, rather than focusing strictly upon the facts. In this sense, we are concerned with how the process of attributing meanings occurs and how the coloniser and the colonised perceive it. Thus, the main goals of the paper are nevertheless conceptual, aimed at disclosing the contours of a specific contemporary biopolitical constellation that congeals with developments in geopolitics, thus consolidating a distinctive colonising project.

In the molecular age - the most recent phase of this project - biotechnology allows the fabrication of life itself, in other terms, the process of (re)creation of life is possible through molecular engineering. As Cooper (2015: 259) explains, biotechnology 'refers to any intervention that seeks to disrupt, suspend, accumulate and reanimate the temporal possibilities of the living body'. Thus we draw upon Dillon and Lobo-Guerrero's (2008) definition of 'pluripotent' life as the primary resource in the process of life fabrication, which can be used to (re)create all other living material. Specifically, for our purposes, we analyse the pluripotency of the seed, its genetic manipulation, and its place in the entire agricultural scheme.

We sought to identify which strategies (re)create/(re)use colonial temporalities to legitimise the control over 'pluripotent' life within the context of agriculture, by using the concepts of 'colonial amnesia' and 'colonial nostalgia' (Gregory 2004) as an effort to demarcate colonisation from the perspective of the colonised. As a whole, we intended to understand how agriculture has become a means of (re)colonisation in neo-liberalism due to practices that occur within international trade. Specifically, our aspiration is to identify 
which altered temporalities are invoked in the use of biotechnology to exert control over 'pluripotent' life.

We originally proceeded from the hypothesis that the apparatuses of control over life impose a temporality based upon a cycle of globalised capital (re)production, which counters local spatio-temporalities of traditional agriculture. For this purpose, we revisit Arendt's (1958) critique of a processual time and her proposal of a time of the interval, in which the process of life fabrication is involved. The conception of a continuous time of life remits to the pretension of eternity, whereas the idea of a time of interval renders it finite, and as such, each life individually has a significance, not as linear time but as remembrance, notions that we appraise with Gregory's (2004) concepts of colonial amnesia and colonial nostalgia, respectively.

This work uses a post-colonial approach ${ }^{1}$ and its junction with Foucault's concepts of biopolitics ${ }^{2}$ and security dispositif ${ }^{3}$ while analysing different temporalities by contemplating the perspective of a reclaimed colonial past and present situated within the project evaluated. This option was chosen as a means of clarifying how biotechnology uses a large array of images and temporalities to (re)create mechanisms of what we conceptualise as neo-agro-colonialism. Therefore, it is necessary to evaluate their implication for the very notion of 'pluripontent' life and, thus, their effect on the fabrication of life as a (re)colonising mechanism.

\section{Neo-agro-colonialism as an expression of the international division of power}

In this initial section, we aim to interpret the current reality by referencing the past in order to explore a recurring colonial logic, as present temporalities are conditioned to remit to circumstances of colonialism. Specifically we discuss a process of (re)colonisation through free trade, which we conceptualise differently from the traditional literature.

Neo-colonialism takes place as an extension of the colonial context; it occurs when economic, political, or even cultural pressure is exerted to control and influence the order of things in other states (Bhabha 2004; Larsen 2005). Modern colonialism is present in many different spheres, but of particular note is what has been taking place within agriculture globally. As we know, agriculture is continually being redesigned by the use of technology; however, this occurs with much greater intensity in capitalist agriculture as is expressed through its Green Revolutions. Yet to many, it is still unclear that the articulations between capitalist agriculture and the international market is the determining factor in how these technologies are used. This straightening relationship is worrisome because it leads to an intensified transition from the production of food, as a means of existence, to commodities, as a good to be traded (Patel 2012; De Schutter 2015), which results in many nefarious social and environmental consequences (Barbosa Junior and Coca 2015). Furthermore, it is important to note that this dynamic also took place in earlier colonial contexts, such as the $17^{\text {th }}$ century sugar trades, but in a different way than has been occurring in neo-liberalism since the 1990s. 
The expression 'agro-imperialism' is more commonly used to reference investors from high-income countries buying up land in middle- and low-income countries to grow food ${ }^{4}$ (Moyo, Yeros and Jha 2012; Ractliffe 2014). However, this definition does not encompass the full extent of the practices and subjectivities that are tied to the use of techniques, representations, and performances present in this process (Gregory 2001; Rose 2007a), even though a few broach the theme of genetic control and manipulation over seeds secondarily - for instance, Islam (2004) and Ractliffe (2014) are the exception promoting a further analysis. Therefore, we explore a multidimensional definition of the concept offered.

Neo-agro-colonialism is currently a reality of the agrarian question ${ }^{5}$ (Amin 2012; Patnaik 2014), which can no longer be approached by studying the relations within and among countries, for it has expanded, as McMichael (2012) explains, to the international market. That is to say that at present the agrarian question fits into a process of neo-colonialism - which now occurs through international trade - where a distinction between countries that export and import food is a determining aspect. Although states maintain an important role, the protagonism is currently exerted by private companies (HighQuest Partners 2010), who gain the most, while the costs are divided out between the environment and the rural poor. Neo-liberalism and the international corporate food regime shaped a monopoly-controlled global agri-food system, which has led to a new conflict between the peasantry and multinational agribusiness.

To put this into perspective, today peasant-based and not industrial farming plays the most critical role for global food production. For instance, even while constituting more than $98 \%$ of all of the world's farms, peasant farmers occupy only $53 \%$ of agricultural land (Graeub et al 2015). Even more so, the industrial food chain uses $70 \%$ of agricultural resources to provide a mere $30 \%$ of the world's food, whereas the peasant food web produces the remaining $70 \%$, with only $30 \%$ of the resources (ETC Group 2013).

\section{Conceptualising neo-agro-colonialism in the molecular age}

As we can see, capital does not necessarily translate into food, and countries that possess ample wealth have been investing in new technologies and disseminating these technologies in foreign countries with the intent to promote the establishment of a steady stream of agricultural imports (Islam 2004). For this reason, with neo-agro-colonialism we introduce the notion of control over 'new territories' (Rose 2007a) - over bodies and life - to the original understanding of control over fertile land from agro-colonialism. That is to say, if you are able to have control over life itself, you can control all other aspects of life and no longer need to control large expanses of territory, in the classical sense.

Now, more than ever, within neo-agro-colonialism, control over people's lives is essential for those who benefit from the multilateral free trade system, but there is the need to draw a distinction between the control that existed in traditional colonialism - with slave labour as a means of production - and the control that is now exerted trough biotechnology. Patents that result from biotechnological advances have become a tool of mercantilisation, ${ }^{6}$ turning life into an asset (Kho 2012), and thus into a device for profit generation that remits to the very notion of enslaved life. 
While labour played a key role in the process of industrialisation, after the Green Revolution the most important means of extracting resource is no longer control over labour, but control over technology. At first technological advances in agriculture meant an abundance of cheap labour for urban centres, where the displaced peasant population was generally incorporated in the subpar process of salaried employment that was imposed in a market-based society and its means of production. However this model has not been sufficient to absorb all the newly displaced from the countryside in the era of globalisation. Nevertheless, within this new arrangement, labour is still a significant point of extraction, even after the Green Revolution. Therefore, it is important to note that the 'surplus' displaced labour often crosses borders to become migrant surplus of exploited labour in high-income countries' fields, working throughout the fruit and produce industry, as well as in meatpacking, fisheries, etc.

As a whole, the global competitiveness promoted by the World Trade Organization (WTO) has changed the scenario of food production and consumption (Barbosa Junior and Coca 2015). The pursuit of increased productivity brought about labour-saving technologies that resulted in mass marginalisation without the possibility of absorbing the marginalised (Amin 2012).

With these changes, the colonial logic of absence and presence (Said 1979; Bhabha 2004) has been transformed and is more than ever relevant in the present. The perception that natives had to undertake agricultural labour for exogenous interests - supplying the European colonisers through the instrumental use of mita $^{7}$ - has been translated into our current reality of the molecular age, where the control over peasants, as the object of power and capital accumulation, takes on a dissimilar form. This is done by creating the impression of absence to undervalue local practices of resource management, through the notion that peasant agriculture is unable to supply a growing population. With promises of surplus output as a means of producing more food and ending hunger, thus arises the myth that technology is the solution to global famine (Nally 2016).

To this end, our intent is to explore the temporalities that condition the structures of neo-colonial agriculture. Hence, it is essential to reflect upon the context of neo-agrocolonialism in a molecular age, where the production of binaries is addressed to (re)assess/(re)imagine dissimilar temporalities. In this enterprise, the notions of temporal propinquity (presence) or remoteness (absence) are expressed in terms of remembrance of colonial contexts.

These mechanisms are used by some countries that are largely dependent on others for food, which results in anxiety, for this is a resource that maintains the biological metabolism, quite literally allowing the population to live. This anxiety is principally a consequence of the fear that this flow will cease. The tensions between coloniser and colonised are well documented, with the mechanisms used by the former to exert control over the latter largely explored. Less discussed is the effect that the colonised has over the coloniser. For while a structure was instituted that allowed commands to flow exclusively top-down, there is always the fear that these commands would not be obeyed. This caused anxiety within the coloniser (Bhabha 2004) - as well as food-importing governments generally and, moreover, their populations. Currently, this same process can be identified in the 
anxiety that exists in international agricultural trade and, as we explained, dependency in this relation has changed, accentuating the anxiety even further. Therefore, neo-agrocolonialism derives from the desire of food-importing countries, who lack faith in the international market, to have greater control over their food supply (Barbosa Junior and Pfrimer 2016). Consequently, it is essential to understand that neo-agro-colonialism is both a driver of the neo-liberal agriculture trade model and a response to its failings.

As we demonstrate in the following section, two aspects of neo-agro-colonialism biotechnology and land-grabbing - are exploited in order to advance neo-liberal interests. In other words, biotechnology justifies the adoption of technological methods that supposedly could result in higher yielding crops, just as land-grabbing is employed as a tool to legitimise the flexibilisation of land tenure norms abroad. In the homo economicus rationale, these mechanisms would hypothetically guarantee larger benefits and production. However, these aforementioned features of neo-agro-colonialism are, in the name of surplus, responsible for the disruption of traditional knowledges and peasant agriculture.

Temporally situated in the molecular age, this can be understood generally through two periods, from the Second Green Revolution in the 1970s - with the introduction of biotechnology - until the 2008 food crisis, and from that point forward - where the inabilities of the multilateral free trade systems lead to the expansion of unilateral actions (Barbosa Junior and Pfrimer 2016). The first period can be perceived as the merging of capitalist agriculture and the free trade regime, while thereafter mercantilist postures, such as land-grabbing (McMichael 2013b), are taken as a response to the system's intrinsic failings. These represent both structural and conjuncture periods, respectively, but can singularly be understood as composing what McMichael (2013a) denotes as the transition to, and implementation of, the third food regime, which began in the 1980s, when corporations took on the central role. Within this reading, states act as instruments of corporate capital, conditioning the scenarios discussed in sequence. Consequently, we analyse this course by exploring the fungibility between geopolitics and biopolitics.

\section{Control over territories or control of biotechnology? Assessing power relations and invoked spatio-temporalities in the process of life fabrication}

In this section of the paper, we appraise the main mechanism through which geopolitics transforms into biopolitics and the converse, discussing some intersecting themes among them. While inquiring about the geopolitics of disease, Ingram (2009) remarks upon a lack of more appropriate theorisation of this process. For our scope, it is essential to verify in which ways this conversion makes feasible the (re)production of new forms of postcolonial spatio-temporalities. As elaborated before, the recent advances of technologies of life fabrication are now changing the production of 'the self' through the process of manipulating life at the molecular level (Rose 2007a).

Having addressed the distinction between agro-colonialism, in a classical sense, and its new arrangements in the molecular age, it becomes important to shed light on the 
mechanisms that enable neo-agro-colonialism to be continuously (re)produced. The idea that we mean to solidify is that the modes of exerting power have changed within this context. As new technologies allow the instrumentalisation of power over novel strategic realms, resulting in distinct forms of colonial strategies that are at the disposal of hegemonic collectives.

As underpinned by Foucault (2003), the power exerted by the territorial state was overlaid via a new correlation of power, in which life became the new strategic realm to be tamed through a security dispositif. In this perspective, control over life becomes a meaningful feature for exerting sovereignty in the molecular age, since the manipulation of life through biotechnology stands as the instrumentalisation of power by resorting to time expansion/compression in order to enframe territory - see Table 1. As Harvey (1992) puts it, the contemporary era is essentially characterised by time-space compression as an outcome of the agency of technological innovation, whereby spatial and temporal distances are condensed. To this end, Said (1979) and Gregory (2004) highlight the impact of imaginative geographies in which performances and representations of space-time accentuates differences and folds them into distance.

Table 1 - Geopolitics and Biopolitics as Altering Mechanisms of Biosecurity

\begin{tabular}{llllll}
\hline Discipline & Strategic realm & Ideology & Scale & Dimension & Mechanism \\
\hline Geopolitics & Territory & Security & $\begin{array}{l}\text { International, national, } \\
\text { regional }\end{array}$ & Space & Land-grabbing \\
Biopolitics & Life & Freedom & $\begin{array}{l}\text { Population, body, cells, Time } \\
\text { genes }\end{array}$ & Biotechnology \\
\hline
\end{tabular}

Source: Compiled by the authors.

Departing from this idea, we do not aim to assert that biopolitics and geopolitics are the sole apparatus for exerting power, but that in the molecular age they are the central instruments for doing so. Furthermore, be it altering geopolitics into biopolitics or the converse - either is possible - nonetheless, due to the fact that the time of a territory is in practice inexorable, the manipulation of the time of a species' life is consequently much more feasible. Thus, in some respect, security is not opposed to freedom, as long as the latter is understood as the contingent developmental freedom of the biological existence and its circulation (Dillon and Lobo-Guerrero 2008). In this scheme, geopolitics and biopolitics are not directly opposed. To this end, as long as technological apparatuses - discourse, practices, objects, and so on - constitute socio-material networks, biopolitics and geopolitics can be described as different sides of the same coin (Ingram 2009; 2010).

The process of disclosing geopolitics into biopolitics, and the inverse, is also corroborated by Dillon and Guerrero's (2008: 287) assertion that:

Biopolitics thus secures by instantiating a general economy of the contingent throughout all the processes of circulation which impinge upon species existence. That is why we can now say that in an age gone global the biopolitical problematisation of security has 
become the imperial struggle not simply to seize territory, control resources or even reconfigure state apparatuses - although these remain traditional security concerns - but to secure the changing and manifold processes of global circulation as such.

However, while approaching this matter, some precaution should be taken in order to adapt these concepts to the precise context of neo-agro-colonialism. Therefore, it is necessary to acknowledge the specificities of neo-agro-colonialism in the molecular age. Departing from this prism, the geopolitical dimension of neo-agro-colonialism is largely characterised by the control over lands and the resources they offer for producing food for their own populations. Both traditional and new centres of power take this course, as we demonstrate below.

\section{Geopolitics, land-grabbing and the spatialities of colonialism}

Countries that have recently experienced large income growth do not necessarily have sufficient agricultural potential to supply their population with food, ${ }^{8}$ and these high-income countries - particularly in the Middle East and Asia (Martin and Palat 2014) - are outsourcing food production to middle- and low-income and food-insecure countries in Latin America, Africa, and Southeast Asia (Costantino 2014) - see Figure 1. This is a course where countries, or other private capital ventures within these, promote investments overseas to address their own food security concerns. As Nally (2015: 341) explains, 'Foreign land acquisitions thus became an exit strategy from import dependency by firstly enabling these states to by-pass an increasingly volatile global food economy; and secondly, ensuring access to future food supplies via the vertical integration of primary production'.

Figure 1 - World Land-Grab

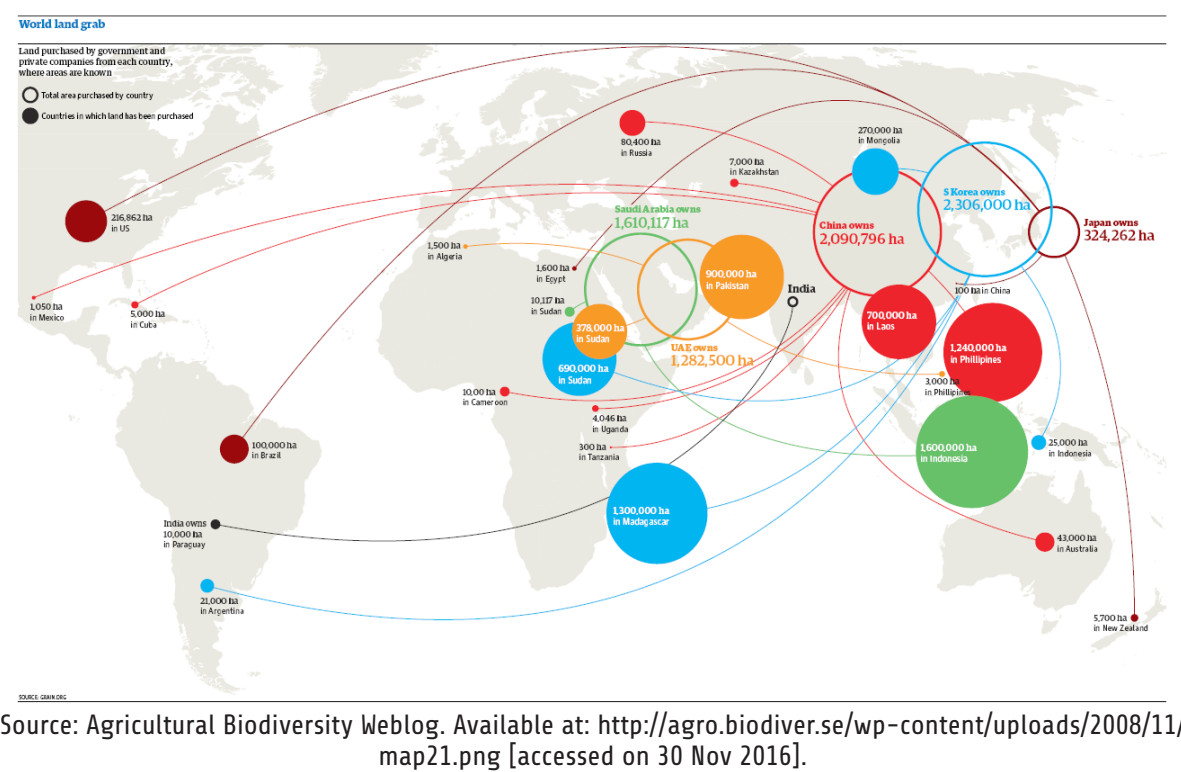


In addition, as a consequence of this process, the control of expanses of land abroad via transnational corporations imposes an agricultural model in accordance with Western countries' techniques, for instance through the use of biotechnology, which, as Graddy (2014) demonstrates, results in a homogenisation of food globally. In this perspective, controlling territory is a way to foster the manipulation of agricultural practices and genetic life in order to manage a crops' time to flourish and, consequently, to be harvested. This clearly implies a neo-agro-colonial spatiality, since traditional agricultural knowledges are practiced nowadays on the margins of global capitalism, both physically (in rural settlements and urban gardens globally) and symbolically (as denoted by 'alternative' agriculture), therefore configuring what Said (1979) calls dispute over geography.

The direct acquisition of land - mostly fertile agricultural land and, although not always addressed, the accompanying water resources - by foreign initiatives is the most explored aspect of agro-colonialism. Different names have been given to this practice, such as 'overseas farming', but more widespread is the use of the term 'land-grabbing' (Moyo, Yeros and Jha 2012). When land-grabbing ${ }^{9}$ was first debated, there was much discussion on whether it was neo-colonialism or 'development' (Robertson and Pinstrup-Andersen 2010). While foreign investors claim to be promoting growth, contesters insist it is opportunism that materialises as exploitation. Although the land is mostly purchased by private companies, it is generally understood that the interest of states are typically behind them. Factors driving the global acquisition of land include: i) development aid shortfalls, ii) the global food crisis, iii) the growing middle class in middle and high-income countries, and iv) the increasing acceptance of biofuels as a viable alternative source of fuel (Robertson and Pinstrup-Andersen 2010).

This dispute can even be identified within international institutions such as the United Nations (UN). Originally, the UN recognised the rush to buy farmland as 'neo-colonialism' but later softened its stance, calling it 'direct foreign investment' (Reguly 2009). In the latter, the foreign investor's objective of securing food supply through land purchases is depicted as a 'win-win' proposition. It is important, however, to ask who in fact is winning, how much, and at whose expense. This dispute can be understood as a conflict of discourse, where the interest of the coloniser is placed before the lives of the colonised.

To add depth to this discussion, it is important to clarify the tensions and convergences between economically and geopolitically dissimilar kinds of power. For instance, much of the demand for agricultural goods and land comes from geographical sites - such as high-income Asian and Middle Eastern nations, as we address elsewhere (Barbosa Junior and Pfrimer 2016) - different from the conventional geopolitical sites of power in the North Atlantic. Thus, it is important to understand the complexity of the dimensions of neo-agro-colonialism. Even while critiquing the colonising impulses of the geopolitical centres of power, it is essential to understand that the demand for the colonised world's land, seeds, and other resources comes from many sources. 


\section{Biopolitics, biotechnology and colonial temporalities}

In order to understand the dynamics of control over life, it is essential to use the concept of biopolitics. The biopolitcal lens directs our gaze towards the future, for it perceives time as that of the species - and thus timelessness - and not of the individual - or as Arendt (1958) puts it, time of the interval. This notion of continuity leads to the conception of processual time as infinite, which is now joined with the new understanding of life as an asset to be continuously reduced for market interests. Therefore, the anxiety of the coloniser is directed towards the myth of the eternal reproduction of life, through the institution of market-oriented mechanisms, and thus situated simultaneously within the logic of depeasantisation and the sacralisation of markets (Nally 2015).

Nonetheless, Arendt (1958) reminds us that this was the sort of tool used to control life in totalitarian regimes, understood in terms of zoe, referring to an idea of entity that is similar to the species. In this sense, life itself - without individuality - is empty life deprived of narratives or memory dispossessed of its very essence (Braun 2007). This suggests that the time of the interval is conceived as a life story that can be passed down through the generations. This is key, for remembrance constitutes a response to human mortality that moves in the opposite direction to market-determined uses of life. The time of the interval does not fit into a metric temporality, as the temporal cycle needs to be accelerated within the directives of capital (re)production, which leads to anachronism. Conversely, as Deloughrey (1999) reasserts, while commenting on Patricia Grace's notion of spiral temporality, rather than posing a facile advocation of a time that repeats itself unchangingly, she demonstrates how the idea of spiral times means 'repetition with a difference. Thus, the time of the interval juxtaposes itself within the capitalist temporal cycle, which portrays a sort of resistance.

While it can be argued that seeds themselves do not have memory, they have genetic memory, and, even if perceived as objects, the traditional peasant use of them demonstrates social memory. Consequently, in traditional agriculture, the life of seeds is upheld on remembrance; remarkably this is the very thing that corporate patented control and market use of these genetic reserves strip away. This attempt to reconfigure the time of supposed 'things' relates to the reconfiguration of social time and life itself, which constitutes socio-cultural memory with the people it intersects (Appadurai 1988). From this perspective, the management of life, as zoe, is essential for capitalist purposes, since the deregulation of qualified life (bios) allows more flexible forms of capital (re)production via the instrumentalisation of life. Therefore, a diversity of seeds are homogenised as if they were merely zoe, becoming stripped of their social memories. This process is possible through the use of binaries, to characterise middle- and low-income countries and places through pathologising images in order to (re)create difference, translated into spatial propinquity or remoteness.

Paradoxically, some middle- and low-income countries export their life, their source of life, within a model that claims their livelihoods and resources. Food-importing countries are fed at the expense of starved populations from food exporting countries, and yet there are ample poor, exploited, under-nourished people even in countries considered 'de- 
veloped'. For instance, it has been estimated that two out of three international land deals are in countries facing chronic hunger problems (Oxfam 2012). As a result, what occurs in practice is that the population of these countries that are mostly food-insecure are 'left do die' so that some of those from foreign countries are 'able to live' (Foucault 2003). For this reason, neo-agro-colonialism is more than just the acquisition of land, but a process that relies on the use of colonial temporalities as a strategy to legitimise the use of mechanisms to control life.

Changes brought about by the free market weaken peasant control over land, even in the infrequent contexts where they still maintain it, as they do not retain control over technologies. That is to say that biotechnology ${ }^{10}$ allows the resources of life (genetic resources) to become instrumentalised in a way that they are detained by few within a logic of the capital. Therefore, biotechnology and its resulting patents in the intellectual property regime set the stage for another neo-colonial context as related to agriculture.

This discussion reasserts the distinction drawn between agro-colonialism and neoagro-colonialism. Agro-colonialism is understood within the reframed bases of colonialism and thus gives emphases to the direct control over territory. In contrast, our proposal of neo-agro-colonialism is situated within a new frame of post-colonial analyses that is focussed upon identifying and deconstructing the mechanisms that sanction this control.

That is to say that we seek to identify the apparatuses that continue to reverberate in or influence the colonial condition of thinking, while describing how the processes are currently taking place and which of their elements have become truly significant.

\section{The mechanisms of control over 'pluripotent' life in neo-agro- colonialism and the imposed temporalities of capitalist agriculture}

Dichotomous binaries are important elements to (de)legitimise biopolitical security dispositif. In fact, they permit the instrumental use of apparatuses such as biotechnology and the property rights regime to take place in a way that allows the manipulation of the temporality of life itself in order to enframe territory. In this section, we will elucidate some of the strategies that make use of semantic binaries as a form of fostering neo-agro-colonialist objectives. Following this passage, we will explore the two aforementioned apparatuses.

One of the meaningful characteristics in the context of agriculture nowadays is the presence of an international property regime regulating the appropriation of territories, places, and biomes, and, on the other side, a regime in search of deregulating the process of fabricating life. In this respect, the neo-agro-colonialist phenomenon is interwoven with the process of fabricating life as a way to (re)colonise practices, discourses, and knowledges of traditional places. As Dillon and Lobo-Guerrero (2008) state, the use of biopolitics as a security dispositif is only made possible by the presence of a certain amount of freedom in order to allow a political economy autopoiesis of making life live. In this circumstance, these authors concede that freedom must be of the contingent developmental kind, that is, freedom of biological existence. In other words, the process of life reproduction needs some conditions of freedom. 
In order to comprehend the 'uses and abuses' of life fabrication as a tool of neo-agrocolonialism in a molecular age, we explore the links between the food production chain and the biopolitical apparatuses. Through this analytical procedure, it is possible to understand how the control over 'pluripotent' life potentialises the control over the lives of people. In this sense, the commodification of genes, tissues, cells as life assets draws attention to the emergence of a bioeconomy of living materials irrespective of the specific forms in which it comes (Rose 2007a), such is the case for seeds.

To induce the time it takes a plant to thrive, a series of transitions that growers must adhere to, especially as the seeds are rendered sterile, is conditioned via the genetic manipulation of seeds. For example, this means that the faster crops yield and are harvested, the sooner growers are impinged into buying new seeds. Through this course, the spatiotemporality of peasant communities becomes engendered in accordance with the logic of capital (re)production. Most of these communities are not able grow at this pace, which implicates in the transformation of land tenure, resulting generally in massive migrant flows to urban centres, poverty, and hunger. This process can be regarded as the exhaustion of both biological and social life. In the end, this allows the manipulation of a larger population's livelihoods, as the final goal of the agribusiness industry is not the production of food, understood as a social good, but accumulation of wealth through the production of agricultural products. In other words, as Nally (2011) puts it, 'molecularisation for capital gain'.

In a way, a significant number of those involved in agribusiness companies, contracts, extension, and policy think that integrating more peasant growers into globalised markets will increase global food security. However, even these 'good intentions' end up feeding, and drawing upon, a neo-agro-colonialist mindset, for these relations are, in themselves, nefarious. As now, the economy drives society, rather than the other way around, hence the essential nature of reaching the understanding that liberalised markets are not a prerequisite for rural development (Nally 2016).

\section{Semantic binaries and the manipulation of temporalities}

This process presents both objective and subjective consequences, since it has some impact over the production of social identity (Rose 2007a). The objective dimension of bioeconomy is only made possible by the use of spatial and temporal imaginations. Since, the use of technologies of life fabrication is inherent to the context of modernisation, the use of binary visions intends to legitimise and advance the application of such devices. Therefore, the mobilisation of binaries is part of the very process of production in the context of what Gregory (1995; 2001) called 'imaginative geographies', which 'construct and calibrate the distance between colonizing and colonized societies' (2001: 86). These performances also entail articulations and subjugations of different temporalities, since a post-colonial strategy aims to create a space of rupture and connection between hegemonic and subaltern communities. Therefore, as we have explained, resorting to binaries also mobilises strategies of forgetting (colonial amnesia) and remembrance (colonial nostalgia) of a co- 
lonial past in a present time. This mechanism represents an attempt to (re)create, (re) construct, and articulate certain features of present and past time.

While there is scientific density - validation of discourses and practices scrutinised by Western knowledge - in 'modern' practices that promote 'development' there are also traditional ecological knowledges (TEK) of those who coexisted with their agro-ecosystem for many years (Graddy 2014). That is to say that this is a method imposed by the capitalist, under the cloak of an empty promise of 'development', that subjugates the locality, an aspect that leads to the local agri-food systems becoming culturally colonised. The use of these semantic binaries is demonstrated in Table 2 .

Table 2 - Strategic Semantic Binaries Produced for Neo-Agro-Colonial Purposes

\begin{tabular}{lll}
\hline Strategic binaries & Coloniser & Colonised \\
\hline Forms of knowledge & Scientific & Traditional \\
\hline Attributed value & Society & Nature \\
\hline Life & Asset & Essence \\
\hline Relations & Trading & Sharing \\
\hline Industrial stage & Developed & Developing \\
\hline Scale & International & Local \\
\hline Culture & Civilised & Primitive \\
\hline Temporalities & Metric (clock) & Lived (facts) \\
\hline
\end{tabular}

Source: Compiled by the authors.

Gregory (2004) shows that, for such an endeavour, binaries are disclosed as much to differentiate as to create a certain familiarity among people, places, practices, languages, and so forth. Therefore, binaries are social constructs to measure social proximity and distance in time and space. Sparke (1994) and others, such as Gregory (2004) and Larsen (2005), draw attention to the fact that colonialism is impinged through different forms of power/knowledge which make possible the production of multiple spatio-temporalities. Accordingly, colonial nostalgia assesses colonial images in terms of 'exoticisation' of present contexts as a strategy to create a strange familiarity. Gregory (2004: 10) asserts that the existence of nostalgia for cultures entangled in the process of modern colonisation reverberates as 'mourning the passing of "the traditional", "the unspoiled", "the authentic", and by a romanticised and thoroughly commodified longing for their revival as what Graham Huggan calls "the postcolonial exotic". On the other hand, colonial amnesia manifests itself as a scheme to exclude the 'other' by producing blindness towards the colonial 'different' and thus 'absence' in a colonial gaze.

Interestingly, Gregory (2004) sheds light on a temporal attribute of post-colonial times, assuming that it has changed its prism by critically gazing on the colonial present as continuity of the colonial past. Hence, the focus is directed towards strategies of instantiating the past colonial context as present in an attempt to produce a future free of colonial power. However, in a molecular age, biotechnology represents a biopolitical tool 
to assess the future through the control of life fabrication. Nally (2016), Landecker (2010), and Braun (2007) declare that the technologies of fabricating life open a future in which imaginaries of uncertainty and the imminence of catastrophic times are always reclaimed as a path to justify 'pre-emptive action' in middle- and low-income countries.

\section{Biotechnology as a biopolitical apparatus}

In brief, neo-agro-colonialist practices and performances in the molecular age are made feasible by controlling and manipulating 'pluripotent' life. Nonetheless, this plot is not so simple given the need to stabilise the differences, ruptures, and articulations among colonising and colonised spaces. Therefore, the use of imaginative geographies and temporalities is of ultimate necessity as a means of allowing biopower to operate in-between the subaltern and the hegemonic.

For instance, in 2004, the Organisation for Economic Co-operation and Development (OECD) conceded in a report that bioeconomy is that part of economic activities 'which captures the latent value in biological processes and renewable bioresources to produce improved health and sustainable growth and development' (OECD 2004 cited in Rose 2007a: 17). Interestingly, the report emphasises the strategic importance of a bioeconomy and the control over 'pluripotent' life through the manipulation of life processes. Thus, the economic rationale is lauded as the key mechanism that will turn life processes into assets, thereby assuring sustainable 'development'. In this perspective, the use of imaginative geographies is not naively applied. As we reason in this paper, the production of a bioeconomy and the commodification of life are linked to very idea of producing 'development'. Nevertheless, there is an implicit question to be posed in this argument: development to whom, to which regions? Which countries or regions will foster 'development'?

Therefore, the use of binaries, such as developed/underdeveloped, bioeconomy/traditional economy, and global/local is implicit in the quotation above. What is not mentioned in the text is the fact that life-fabricating technologies are in the hands of the highest income economies. These techniques, hence, ought to be projected to the 'least established areas' where traditional techniques of food production should be replaced by 'modern ones'. For this purpose, the textual mechanism of presence and absence is pushed forward in order to produce a superficial fabrication of 'sameness' and homogeneity among places by concealing the aspects of difference.

Sparke (1994) and Sharp (2006) call attention to the fact that colonialism's discourses and performances strategically deny heterogeneity by producing a hybrid circumstance where the subaltern and hegemonic are supposedly in equal condition. Nonetheless, this idea of sameness is produced by the imposition of hegemonic modes of reasoning over the subaltern culture and modes of reasoning, whereby the processes of identity, construction of the self, ends up reproducing colonial ways of thinking (Quijano 2000; Mignolo 2002). This superficial idea of sameness is the legitimising mechanism of biopolitics when it is applied as a tool of 'development'. This explains how traditional seeds have social memory, while those that are genetically modified and standardised do not, as we discussed earlier. 
When it comes to financing biotech research, one easily notices that the vast majority of the investments are allocated to places and regions of high-income countries. This 'singular' aspect of reality is absent or forgotten in the textual performance aforementioned. As is portrayed in an annex of a Nordic Innovation Centre for the Nordic Council of Ministers' report (see Figure 2), these investments are highly concentrated in high-income countries (Andersen 2008).

Figure 2 - Global Map of Research Investments and Biotech Hotspots
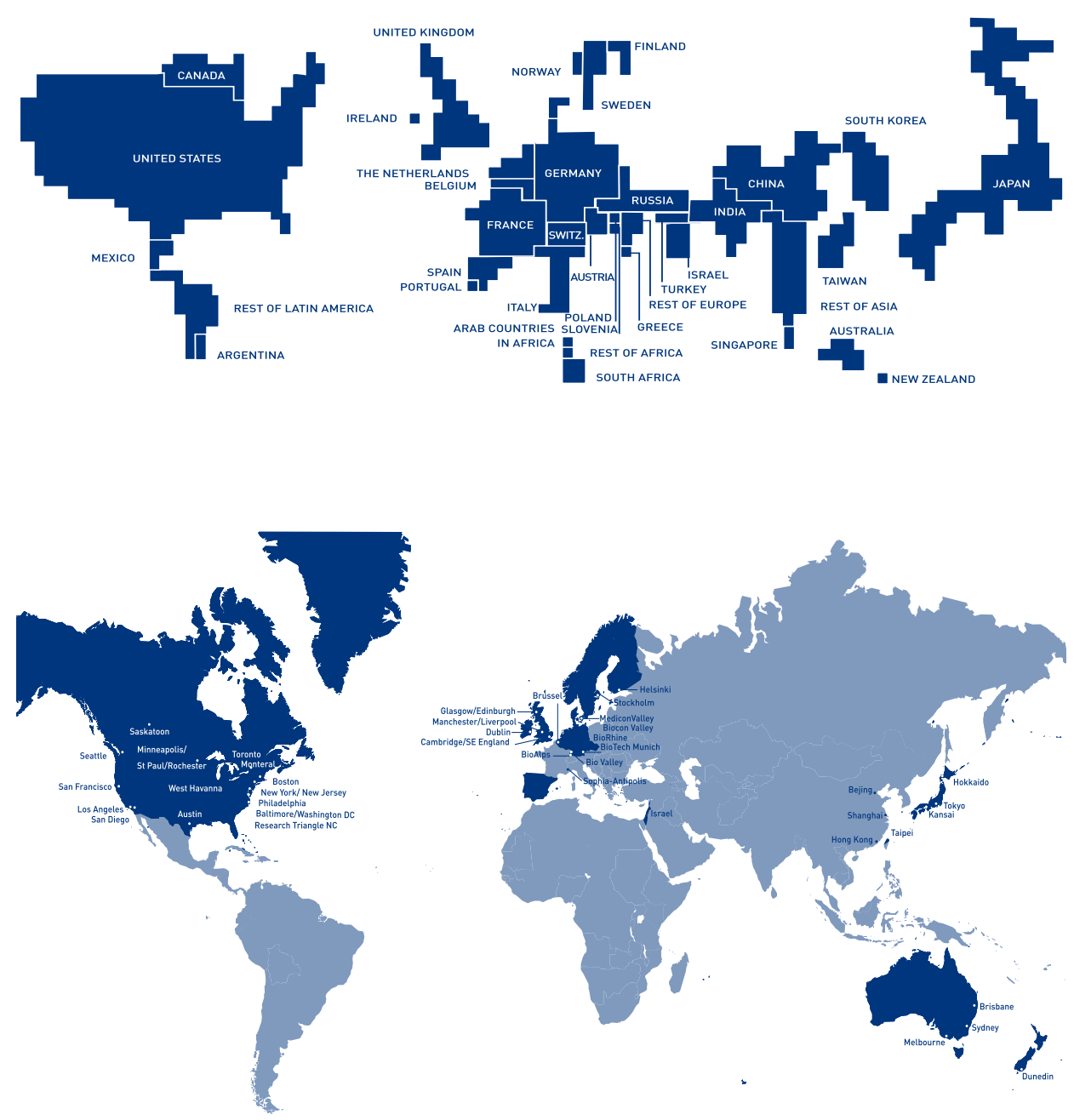

Source: Andersen (2008: Annex III)

The consequences of such a bioeconomic scheme, spread to other parts of the world, should also unleash the imposition of exogenous temporalities upon spaces of traditional agriculture. On the one hand, if high-income countries dispose over technologies that al- 
low for the fabrication of life, on the other hand, many middle- and low-income countries generally dispose over great expanses of fertile land and natural assets. This unequal status amongst regions impinges different temporalities on the spaces of traditional agriculture. In order to bring 'development', the particular idea of turning life into an asset becomes the field of contention among various temporalities. The (re)production of life in a lab with the use of technological apparatuses is aligned with the time for capital reproduction, whereas the (re)production of life in traditional agricultural spaces occurs in conjunction with the temporal dimension for the reproduction of natural processes (Castree 2001). For example, while peasants need long periods to alter nature with the selection of favourable traits by breeding plants over time, market directives endorse instant changes provoked by modern biotechnology in the altering of life. In this sense, Quijano's (2000) notion of the coloniality of power is implicit, as peripheral areas in the global division of labour, particularly where traditional agriculture takes place, are featured as 'backward' for relying upon TEK.

The temporality imposed by the processes of capital (re)production is essentially grounded on the commensurability of lived time in terms of metric units, while the organic temporalities are measured in terms of experienced events. As Castree (2009) explains, a clock's time is a product of the capitalist system intended to impose a disciplinary pressure within contemporary societies so that surplus value can be produced, even if the manipulation of life's temporality is necessary for this purpose. Landecker (2010: 228) summarises this process by stating that:

The scale implied by the involvement of these companies speaks to the industrialization of the biotechnology's interventions in temporality and plasticity as 'biological'. The ability to make cells live differently in time, so important to changing concepts in cell biology, connects at this juncture with the infrastructure of exchange which the material base of research gets spread around the world. The techniques exploiting the malleability of biological time, which treat a living cell population as a thing that can be expanded in space and suspended in time, literally get packaged and delivered into disparate laboratories at disparate times.

In other words, organic time is suspended, halted, reanimated, overlapped, and surpassed by other hegemonic temporalities in the name of (re)producing capital, and the colonising collectives of humans and non-humans. Therefore, the construction of spatiotemporalities is also a strategic realm for neo-agro-colonialism, demonstrating how the emergence of bio-economy refers to the various ways in which vitality itself has become a potential source of value.

The emergence of a molecular age remits to the idea of controlling and mobilising a whole set of human and non-human actants by simply controlling the building blocks of life. Interestingly, the control over the genetic manipulation of seeds in agriculture makes it possible to control the whole chain of production. The ETC Group demonstrates how 
the seed market is not the most profitable but the most strategic. According to this activist organisation, the seed market in 2013 accounted for only 32 billion US dollars a year, while the other agribusiness market shares - pesticides, agricultural equipment, and fertiliser, respectively - account for almost ten times that amount together (ETC Group 2015).

Quintessentially, seeds embody the perpetuation of the cycle of life. However, by being positioned as a strategic asset in capitalist agriculture, they are genetically modified and this essence is stripped from them. For instance, even though hybrid seeds were already biologically single-season, even before patents, peasant growers who breed them, not corporations, maintained the domain. Now they grow within the logic and temporality of capitalism. For instance, 'soybean has become one of a number of transgenic crops fabricated under the trademark Roundup Ready ${ }^{\mathrm{Tm}}$ that have been genetically enrolled to tolerate a broad spectrum (i.e. indiscriminate) glyphosate herbicide Roundup ${ }^{\oplus}$ (Whatmore 2002: 125). That is to say, the genetic modification of seeds conditions new markets for agricultural products.

In essence this project is not only a plot mobilised by states but rather involves and inscribes different bodies, such as enterprises, transnational companies, think tanks, research funding, non-governmental organisations, among others. As such, these collectivities are engaged in governing the bioeconomy. Hence, the vision that the process of neoagro-colonialism is conducted principally by state-centric actors is fraught with problems (Rose 2007a), as McMichael (2013a) shows us. For example, a confined number of six transnational companies account for $75 \%$ of the global agro-chemical market and $63 \%$ of the commercial seed market (ETC Group 2015). It is also necessary to understand that the state is not monolithic; many in the USDA bureaucracy, for instance, think these practices will help farmers. Remarkably, they defend a larger hegemony even while posing good intentions.

\section{The intellectual property regime, patents and biopiracy}

Patenting knowledge is another central tool used by neo-agro-colonialism in the strategy of fabricating life. Transnational corporations are appropriating much of the TEK produced by the indigenous and peasant communities (Graddy 2014). This occurs through a process of distancing and approximation (Gregory 2001). In a first moment, a process of distancing and estrangement is carried out with the intent of disqualifying TEK on a scientific basis. Since these traditional communities make use of their knowledges for quotidian practical reasons, the Western scientific logic is not at the core of their rationale. Therefore, most of the knowledge produced in the middle- and low-income countries is perceived and qualified as not scientifically valid, in other words, backward. To this end, colonial remembrance of 'tropical nature' as being fallen and wretched is mobilised.

This initial phase sets the stage for the imposition of more advanced agriculture techniques. In this perspective, local knowledges should be neglected and left aside by traditional communities, who should adhere to techniques validated by scientific norms that are produced in other places. This however, results in a paradox, where disqualified 
traditional knowledges end up being appropriated by transnational companies, which becomes possible once the traditional knowledges are translated into scientific practices and performances and then validated under academic scrutiny. Consequently, what was once disqualified becomes qualified with little or no innovation. Thus, scientificisation of TEK enables it to be patented by transnational corporations (Graddy 2014). As a result, practices that are a product of TEK that before had 'no scientific attributes' are no longer allowed to be performed by traditional communities given that these became the property of transnational corporations. In this final stage, there is a practice of familiarity or approximation. From that moment on, TEK is not strange, since it has attributes in common with the colonising culture: the Western scientific rationale. This implies, as Mignolo (2002) argues, a geopolitics of knowledge, since there is a knowledge-emitting centre that subjugates other local histories. As the author demonstrates, Western history and the history of capitalism run parallel with and complement each other.

While analysing the economic consequences of wheat seeds' genetic modification through the prism of Schumpeter's concept of 'destructive creation', Perkins (1997: 25) described a similar process:

Schumpeter envisioned creative destruction operating without heavy government involvement in the details of change. After 1945, however, governments began consciously to promote new technologies to develop other countries, which was a euphemism for promoting creative destruction. Perhaps development was one of the most ironic concepts to enter late-twentieth-century language, and in basic ways its meaning was tied to the results of plant-breeding science and the yield transformation.

In other words, creative destruction implies a destruction of other knowledges in favour of a 'modern' one. For authors such as Kerckhoffs (2012) and Shiva (2001), this phenomenon is portrayed as biopiracy: a new form of colonialism. According to these authors, in colonial times, the West legitimised its acquisition of indigenous people's land evoking the colonial imaginaries of terra nullius, therefore treating them as public domain. Nowadays the same strategy is applied when it comes to biodiversity and the intellectual commons. Shiva (2001) argues that this new colonial strategy is grounded on what she called bio nullius. In other words, it makes reference to treating TEK 'as empty of prior creativity and prior rights and hence available for ownership through the claim of invention' (Shiva 2001: 49).

These are posteriorly (re)introduced as a completely new form of life, playing off colonial amnesia. In contrast, a great variety of potatoes and seedlings that were stored for study in laboratories throughout Western centres ended up repatriated to Peru, recognised as the origin place of these species. In Graddy's (2014) assessments, the repatriation of these stored seeds, occurred through practices of remembering and regenerating placebased agrarian practices centred around celebrations, festivals, and ceremonies. In this sense, seeds that were once stored are reintroduced via mechanisms of colonial nostalgia. 
According to a map produced by the OECD in 2009, it is unambiguous that a large majority of the rights produced by patents are created in favour of high-income countries. Interestingly, even some states in high-income countries, such as Massachusetts and California, are more prominent than the sum of most of the middle- and low-income countries in patenting knowledge - see Figure 3. For these reasons, the appropriation of TEK and life forms through patenting in the intellectual property regime is a conspicuous strategy of neo-agro-colonialism and a mode of turning life into an asset.

Figure 3 - Intensity and Number of Patents in 2009

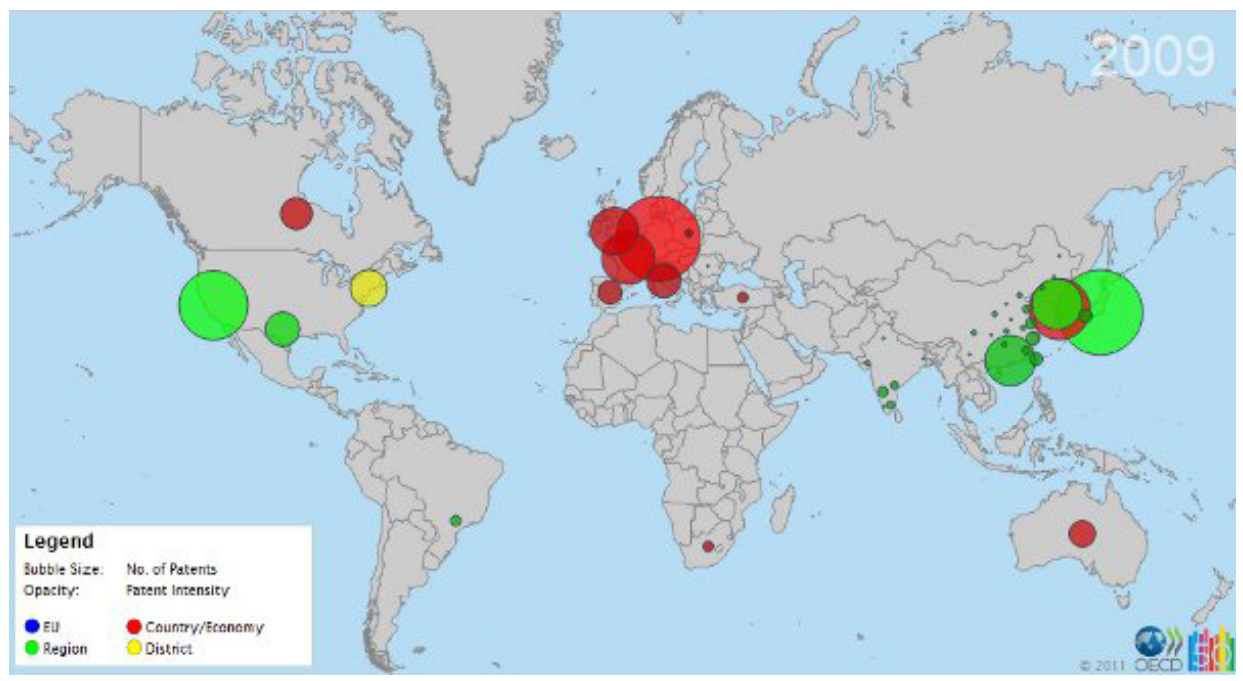

Source: Citylab. Available at: http://www.citylab.com/work/2012/04/spiky-world-innovation/1592/ [accessed 30 Nov 2016].

Both the control over biotechnology and biopiracy are examples of how new forms of bio-power can be exerted in a molecular age, within the scope of neo-agro-colonialism. Although these two cases do not exhaust all the neo-agro-colonial forms in the molecular age, they exemplify how neo-agro-colonialism embodies multifarious practices that are not encompassed by most of the traditional conceptualisations of such phenomena.

\section{Final considerations}

We conceptualise neo-agro-colonialism as a project temporally situated in the molecular age, with the intention of demonstrating the analytical value of the approach in association with a central biopolitical problem, while considering the efforts designed towards controlling agricultural (re)production, facilitated by the scientific and technological developments of recent years in molecular biology. Although land acquisition was the original symptom, in this paper we offer a more complete diagnosis, explaining the nontangible aspect of the neo-agro-colonial process and its spatio-temporal implications. As we explored the relationship between the temporality of biological life and the temporality 
of capital (re)production - in order to understand which colonial temporalities are being (re)introduced in the use of biotechnology as a security apparatus to exert control over life itself - we made several findings.

One of the findings that stands out is the fusion between geopolitics and biopolitics. Specifically, this was made possible by the expansion of technology to other domains. In this perspective, while in previous times colonialism was exerted through control over territory, in a molecular age neo-agro-colonialism is practiced though control over life and the manipulation of time. This discovery leads us to a thought-provoking conclusion.

Most significantly, we identify that it is the very manipulation of life's temporality that allows capital to be (re)produced. The (re)production of life in a molecular age conditions the creation of necessity, resulting in linear and anachronic time, which literally exhausts life. Thus, we conclude that neo-agro-colonialism is a new regime of unequal exchange that remounts the temporalities of colonialism relying upon the control of biotechnology and other mechanisms of fabricating life that are situated within the international market.

Looking forward, on the agri-biotech front genomic editing marks a new wave of agribiotechnologies. Specifically, a new, remarkably flexible genetic engineering tool known as CRISPR used for genome manipulation, which acts upon the activation or repression of target genes, is anticipated to drastically reduce the time taken to alter life (Montenegro 2016). Hence, it becomes evident how the broader phenomenon breached in this paper keeps repeating itself.

While in this work we explore the instrumental use of colonial temporalities during this newest phase of agrarian capitalism, in future it becomes essential to address the efforts of the marginalised of the world to reclaim or abduct time from these neo-agrocolonial trappings - in short, the temporalities of resistance. After all, while analysing the (re)production of colonial time in agrarian relations, we would be remiss to present the temporal (re)configurations of the current order as a one-sided effort; there are multiple temporal arrangements imagined by peasants and other subaltern knowledge-holders of the world. This question of struggle against temporal totalitarianism was at the heart of Arendt's philosophy as well. In her words, 'the source of freedom remains present even when political life has become petrified and political action impotent to interrupt automatic processes' (Arendt 1961: 169).

\section{Notes}

1 There are many post-colonial approaches, as there are multiple post-colonial realities. In this paper, we draw mostly upon the works of Shiva (2001), Gregory (2001), Bhabha (2004) and Sharp (2006) to analyse how agricultural relations are conducted internationally as a means to better comprehend a world still is marked by colonialism.

2 It is important to note that many of the quotations and references we draw upon analyse the biopolitics of human genome biotech; however, we are extending these analyses to plant biotech in the context of agriculture. In this perspective, the concept of biopolitics references an Arendtian and Foucaultian tradition in which the control over life is qualified as 'make live' or 'let die'.

3 Dispositif refers to various institutional, physical, and administrative mechanisms, as well as knowledge structures, that allow and preserve the exercise of power within a social body. Thus, it is a strategy of thought that operates within the interaction of discursive behaviour, non-discursive behaviour, and manifestation 
of knowledges by means of acts and behaviours, or as Foucault (1980: 194) himself puts it, 'the said as much as the unsaid'.

4 While not centrally discussed here, the role of financialisation and speculation in agriculture cannot be overlooked, for it involves a multitude of functions other than the mere growing of food traditionally referenced. An illustrative example is the effort to address the energy crisis through agricultural production of biofuels (Robertson and Pinstrup-Andersen 2010), with an integration of the food and energy markets as described in McMichael's (2013a) third food regime.

5 The 'agrarian question', as presented in Kautsky's (1988) work, is understood as the study of capitalism's impact on agrarian society and the role of agriculture in capitalist development. It was not originally considered directly as a component of neocolonialism.

6 Interestingly, mercantilism contrasts with economic liberalism. Mercantilists are self-centred and selfregarding in their approach, while liberals emphasise policies and philosophies that favour co-operation. Yet within the WTO-trade paradigm, mercantilist practices are recurrent and maintain the multilateral trade system itself, with states and corporations at the centre of interest and not people.

7 Collective work practices of natives in the pre-colonial Andean region.

8 When referencing insufficient agricultural potential, we indicate that a country does not autonomously dispose over the essential resources to maintain national food supply. In other terms, we reference agricultural land, water, and technology or the amount of these in relation to their population. Where earlier a country could not maintain a population larger than its agricultural potential, now that food can be easily imported this is no longer the case. Specifically, we highlight countries such as Saudi Arabia and United Arab States in the Middle East, and China, South Korea, and Japan in Asia (Barbosa Junior and Pfrimer 2016).

9 In some examples, a clear distinction between coloniser and colonised is not possible in the land-grab phenomenon. It can happen within one country, but a 'grabber' can also be 'grabbed'. A clear example of this is Brazil, where a large portion of territory has been acquired by foreign capital, yet Brazilian private interests also purchase large expanses of land in countries such as Bolivia and Paraguay.

10 Biotechnology is understood as a series of enabling technologies which involve the manipulation of living organisms, or their subcellular components, to develop useful products, processes, or services (NewellMcGloughlin and Re 2006). This type of technology cannot be viewed as a natural project since the manipulation of plant genes involves the appropriation of secular knowledges, and the resulting genetic memory of peasant growers around the world. Conversely, without consideration of this, biotechnology patents first granted in the 1980s recognised transgenic materials and organisms as 'inventions' (Kinchy 2012).

\section{References}

Amin, Samir. 2012. 'Contemporary Imperialism and the Agrarian Question'. Agrarian South: Journal of Political Economy 1(1): 11-26.

Andersen, Jørn Bang. 2008. Establishment of Nordic Innovation Centres in Asia? Oslo.

Appadurai, Arjun, ed. 1988. The Social Life of Things: Commodities in Cultural Perspective. Cambridge: Cambridge University Press.

Arendt, Hannah. 1958. Library The Human Condition. $2^{\text {nd }}$ ed. Chicago: University of Chicago Press. . 1961. Between Past and Future: Six Exercises in Political Thought. New York: The Viking

Press.

Barbosa Junior, Ricardo Cesar, and Estevan Leopoldo de Freitas Coca. 2015. 'The WTO 's International Multilateral Trade System and Its Effects on the Production and Consumption of Food'. Boletim Meridiano 47 16(150): 42-49. 
Barbosa Junior, Ricardo Cesar, and Matheus Hoffmann Pfrimer. 2016. 'Shortcomings of Global Multilateral Agrifood Trade and a New Food-Dependency-Based Protagonism'. Conjuntura Internacional 13(1): 96-103.

Bhabha, Homi K. 2004. The Location of Culture. $2^{\text {nd }}$ ed. London: Routledge.

Braun, Bruce. 2007. 'Biopolitics and the Molecularization of Life'. Cultural Geographies 14(1): 6-28.

Braun, Kathrin. 2007. 'Biopolitics and Temporality in Arendt and Foucault'. Time \& Society 16(1): 5-23.

Castree, Noel. 2001. 'Marxism, Capitalism, and the Production of Nature'. In Noel Castree and Bruce Braun (eds), Social Nature. Malden: Blackwell Publishing, 189-207. 2009. 'The Spatio-Temporality of Capitalism'. Time \& Society 18(1): 26-61.

Castree, Noel, and Bruce Braun. 2002. Social Nature: Theory, Practice and Politics. $2^{\text {nd }}$ ed. Malden: Blackwell Publishing.

Cooper, Melinda. 2015. 'In Vivo Economies: Temporalities of Life and Value'. Journal of Cultural Economy 8(3): 257-9.

Costantino, Agostina. 2014. 'Land Grabbing in Latin America: Another Natural Resource Curse?' Agrarian South: Journal of Political Economy 3: 17-43.

Deloughrey, Elizabeth. 1999. 'The Spiral Temporality of Patricia Grace's “Potiki”'. ARIEL: A Review of International English Literature 30(1): 59-83.

Dillon, Michael G and Luis Lobo-Guerrero. 2008. 'Biopolitics of Security in the 21st Century: An Introduction'. Review of International Studies 34: 265-92.

ETC Group. 2013. With Climate Chaos... Who Will Feed Us? The Industrial Food Chain/The Peasant Food Web. Ottawa.

2015. Mega-Mergers in the Global Agricultural Inputs Sector: Threats to Food Security \& Climate Resilience. Ottawa.

Foucault, Michel. 1980. 'The Confession of the Flesh'. In Colin Gordon (ed), Power/Knowledge: Selected Interviews and Other Writings, 1972-1977. New York: Pantheon Books. pp. 194-228. 2003. Society Must Be Defended: Lectures a the Collège de France, 1975-76. New York: Picador.

Graddy, T Garrett. 2014. 'Situating in Situ: A Critical Geography of Agricultural Biodiversity Conservation in the Peruvian Andes and beyond'. Antipode 46(2): 426-54.

Graeub, Benjamin E, M Jahi Chappell, Hannah Wittman, Samuel Ledermann, Rachel Bezner Kerr and Barbara Gemmill-Herren. 2015. 'The State of Family Farms in the World'. World Development 87: 1-15.

Gregory, Derek. 1995. 'Imaginative Geographies'. Progress in Human Geography 19(4): 447-85. 2001. '(Post)colonialism and the Production of Nature'. In Noel Castree and Bruce Braun (eds), Social Nature. Malden: Blackwell Publishing, pp. 83-111. 2004. The Colonial Present. $1^{\text {st }}$ ed. Malden: Blackwell Publishing.

Harvey, David. 1992. The Condition of Postmodernity: An Enquiry into the Origins of Cultural Change. $4^{\text {th }}$ ed. Cambridge: Blackwell Publishing.

HighQuest Partners, United States. 2010. 'Private Financial Sector Investment in Farmland and Agricultural Infrastructure. OECD Food, Agriculture and Fisheries Working Papers 33: 1-33.

Ingram, Alan. 2009. 'The Geopolitics of Disease'. Geography Compass 3(6): 2084-97. 
. 2010. 'Biosecurity and the International Response to HIV/AIDS: Governmentality, Globalisation and Security’. Area 42(3): 293-301.

Islam, Md Nazrul. 2004. 'Agro-Imperialism - Green Revolution to Biotechnology'. The Daily Star. Available at http://www.thedailystar.net/2004/07/02/d407021501100.htm [Accessed on 1 December 2015].

Kautsky, Karl. 1988. The Agrarian Question: Vol I. London: Zwan Publications.

Kerckhoffs, Dennis. 2012. 'Resisting the Colonization of "Life": Technoscience, Feminist Critique and Contemporary Art'. Universiteit Utrecht.

Kho, Tung-Yi. 2012. 'Intellectual Property Rights and the North-South Contest for Agricultural Germplasm: A Historical Perspective.' Agrarian South: Journal of Political Economy 1(3): 255-90.

Kinchy, Abby. 2012. Seeds, Science and Struggle: The Global Politics of Transgenic Crops. Cambridge: The MIT Press.

Landecker, Hannah. 2010. 'Living Differently in Time: Plasticity, Temporality and Cellular Biotechnologies'. In Jeanette Edwards, Penny Harvey, and Peter Wade (eds), Technologized Images, Technologized Bodies. New York: Berghahn Books, pp. 211-33.

Larsen, Neil. 2005. 'Imperialism, Colonialism, Postcolonialism'. In Henry Schwarz and Sangeeta Ray (eds), A Companion to Postcolonial Studies. Malden: Blackwell Publishing, pp. 23-52.

Martin, William G and Ravi Arvind Palat. 2014. 'Asian Land Acquisitions in Africa: Beyond the "New Bandung” or a "New Colonialism"?' Agrarian South: Journal of Political Economy 3(1): 125-50.

McMichael, Philip. 2012. 'Food Regime Crisis and Revaluing the Agrarian Question'. In Reidar Almås and Hughl Campbel (eds), Rethinking Agricultural Policy Regimes: Food Security, Climate Change and the Future Resilience of Global Agriculture. Bradford: Emerald Group Publishing Limited, pp. 99-122.

.2013a. Food Regimes and Agrarian Questions. Halifax: Fernwood Publishing.

2013b. 'Land Grabbing as Security Mercantilism in International Relations'. Globalizations 10(1): 47-64.

Mignolo, Walter D. 2002. 'The Geopolitics of Knowledge and the Colonial Difference.' South Atlantic Quarterly 101(1): 57-96.

Montenegro, Maywa. 2016. 'CRISPR Is Coming to Agriculture - with Big Implications for Food, Farmers, Consumers and Nature'. Ensia. Available at http://ensia.com/voices/crispr-is-coming-toagriculture-with-big-implications-for-food-farmers-consumers-and-nature/ [Accessed on 1 June 2016].

Moyo, Sam, Paris Yeros, and Praveen Jha. 2012. 'Imperialism and Primitive Accumulation: Notes on the New Scramble for Africa'. Agrarian South: Journal of Political Economy 1(2): 181-203.

Nally, David. 2011. 'The Biopolitics of Food Provisioning. Transactions of the Institute of British Geographers 36(1): 37-53.

. 2015. 'Governing Precarious Lives: Land Grabs, Geopolitics, and "Food Security". Geographical Journal 181(4): 340-9.

. 2016. 'Against Food Security: On Forms of Care and Fields of Violence'. Global Society 30(4):

$558-82$.

Newell-McGloughlin, Martina, and Edward Brian Re. 2006. The Evolution of Biotechnology: From Natufians to Nanotechnology. Dordrecht: Springer. 
OECD. 2004. Meeting of the OECD Committee for Scientific and Technological Policy at Ministerial Level Biotechnology for Sustainable Growth and Development. Paris.

Oxfam. 2012. 'Our Land, Our Lives: Time out on the Global Land Rush'. Oxfam Briefing Note. Available at http://www.oxfam.org/sites/www.oxfam.org/files/bn-land-lives-freeze-041012-en_1.pdf [Accessed on 1 December 2015].

Patel, Rajeev C. 2012. 'Food Sovereignty: Power, Gender, and the Right to Food'. Plos Medicine 9(6): 1-4.

Patnaik, Prabhat. 2014. 'Imperialism and the Agrarian Question'. Agrarian South: Journal of Political Economy 3(1): 1-15.

Patnaik, Utsa. 2015. 'The Origins and Continuation of First World Import Dependence on Developing Countries for Agricultural Products'. Agrarian South: Journal of Political Economy 4(1): 1-21.

Perkins, John H. 1997. Geopolitics and the Green Revolution: Wheat, Genes, and the Cold War. $1^{\text {st }}$ ed. New York: Oxford University Press.

Quijano, Anibal. 2000. 'Coloniality of Power and Eurocentrism in Latin America'. International Sociology 15(2): 201-32.

Ractliffe, Emma. 2014. 'Agro-Imperialism: Colonialism in the $21^{\text {st }}$ Century'. Dartmouth Business Journal: 1-6. Available at http://dartmouthbusinessjournal.com/2014/12/agro-imperialism-colonialism-in-the-21st-century/ [Accessed on 1 December 2015].

Reguly, Eric. 2009. 'Race by Foreign Investors to Secure Food Supply through Land Purchases Can Be "Win-Win" Proposition, FAO Says'. farmlandgrab.org. Available at http://farmlandgrab.org/8928 [Accessed on 1 December 2015].

Robertson, Beth, and Per Pinstrup-Andersen. 2010. 'Global Land Acquisition: Neo-Colonialism or Development Opportunity?’ Food Security 2(3): 271-83.

Rose, Nikolas. 2007a. 'Molecular Politics, Somatic Ethics, and the Spirit of Biocapital. Social Theory \& Health 5(1): 3-29.

2007b. Formation Series The Politics of Life Itself: Biomedicine, Power, and Subjectivity in the Twenty-First Century. New Jersey: Princeton University Press.

Said, Edward W. 1979. Orientalism. New York: Vintage Books.

De Schutter, Olivier. 2015. 'Starving for Answers: Don't Let Food Be the Problem'. Foreign Policy. Available at http://foreignpolicy.com/2015/07/20/starving-for-answers-food-water-united-nations/ [Accessed on 1 December 2015].

Sharp, Joanne P. 2006. 'Feminist and Postcolonial Engagements'. In John Agnew, Katharyne Mitchell, and Gerard Toal (eds), A Companion to Political Geography. Blackwell Publishing, pp. 59-74.

Shiva, Vandana. 2001. Protect or Plunder: Understanding Intellectual Property Rights. London: Zed Books Ltd.

Sparke, Matthew. 1994. 'White Mythologies and Anemic Geographies: A Review'. Environment and Planning D: Society and Space 12(1): 105-23.

Whatmore, Sarah. 2002. Hybrid Geographies: Natures Cultures Spaces. $1^{\text {st }}$ ed. London: SAGE Publications Ltd.

\section{Acknowledgments}

We would like to thank the anonymous reviewers for providing engaging and insightful comments, and Catherine Schwerin for her excellent copy-editing skills. These findings are part of the results 
uncovered while studying the place of genetic resources in the Cerrado biome, situated within NEG's International Security research group's project 'Cerrado between the space of (in)security and National Integration,' and funded by the Goiás Research Foundation (FAPEG).

\section{About the authors}

Matheus Hoffmann Pfrimer is the Professor of Geopolitics and Security Studies, International Relations Program at the Faculty of Social Sciences, Federal University of Goiás (UFG), Brazil. He holds a PhD in Political Geography from the University of São Paulo (USP), having also conducted post-doctoral research at the same institution. He holds a Master's degree in International Relations from Liège University, Belgium, and Bachelors' degrees in both Law (from the Pontifical Catholic University of Goiás - PUC-GO) and Geography (from the Federal University of Goiás - UFG), Brazil. He is currently a Researcher at the Center for Global Studies (NEG), where he holds a grant from the Goiás Research Foundation (FAPEG).

Ricardo César Barbosa Júnior is an undergraduate student in both International Relations at the Federal University of Goiás (UFG) and Law at the Pontifical Catholic University of Goiás (PUC-GO), Brazil. He is currently a PIBIC/CNPq fellow-researcher, and holds the position of Research Assistant at the Center for Global Studies (NEG). He was a Mitacs Globalink Research Intern at the University of British Columbia (UBC), Canada, and an international exchange student at Universidad Autónoma del Caribe (UAC), Colombia. His research focuses mainly on the social and political dimensions of agriculture and food.

Received on 21 July 2016, and approved for publication on 02 November 2016

\section{(cc) BY-NC} https://creativecommons.org/licenses/by-nc/4.0/ 
